\title{
Phytoplankton chlorophyll $a$ in Lake Poyang and its tributaries during dry, mid-dry and wet seasons: a 4-year study
}

\author{
Z. $\mathrm{Wu}^{(1),(2)}, \mathrm{X}$. Lai $^{(1)}$, L. Zhang ${ }^{(1)}$, Y. Cai( ${ }^{(1)}$, Y. Chen ${ }^{(1), \star}$
}

Received October 15, 2013

Revised November 23, 2013

Accepted November 23, 2013

Key-words: Lake Poyang, tributaries, chlorophyll a, light, water retention time

\section{ABSTRACT}

Variations in phytoplankton chlorophyll a were studied in Lake Poyang, and these variations were compared with those observed in its tributaries. Samples were collected from January 2009 to January 2013 during the dry, mid-dry and wet seasons. The study showed that chlorophyll a concentrations were significantly higher in the wet season than in the dry and mid-dry seasons $(p<0.0001)$ in the lake; a comparative analysis of Lake Poyang and its tributaries showed significant differences in chlorophyll a between the two ecosystems during the wet season but not during the dry and mid-dry seasons. During the wet season, the underwater light conditions were significantly elevated and water retention time increased substantially ( $25.5 \mathrm{~d}$ ). In combination, these factors contributed to a significantly higher chlorophyll a concentration during the wet season than that during the dry and mid-dry seasons in the lake; the effect of nutrients on the phytoplankton was not obvious. The large variations in water retention time during the three seasons indicated that Lake Poyang has the combined characteristics of a river and a lake. The short retention times during the dry and mid-dry seasons produced no difference in chlorophyll a between the lake and its tributaries, whereas the long retention time during the wet season facilitated phytoplankton growth in the lake.

\section{RÉSUMÉ}

La chlorophylle a phytoplanctonique dans le lac Poyang et ses affluents pendant les saisons sèche, mi-sèche et humide : une étude de 4 ans

\begin{abstract}
Mots-clés :
Les variations de chlorophylle a phytoplanctonique ont été étudiées dans le lac lac Poyang, affluents, chlorophylle a, lumière, temps de rétention fluents. Les échantillons ont été prélevés de janvier 2009 à janvier 2013 pendant les saisons sèches, mi-sèche et humide. L'étude a montré que les concentrations de chlorophylle a étaient significativement plus élevées en saison des pluies qu'en saison sèche et mi-sèche $(p<0,0001)$ dans le lac; une analyse comparative du lac Poyang et de ses affluents a montré des différences significatives dans la chlorophylle a entre les deux écosystèmes pendant la saison humide, mais pas pendant les saisons sèche et mi-sèche. Pendant la saison des pluies, les conditions d'éclairement sous l'eau ont été significativement plus élevées et le temps de rétention de l'eau a augmenté sensiblement (25,5 jours). La combinaison de
\end{abstract}

(1) State Key Laboratory of Lake Science and Environment, Nanjing Institute of Geography and Limnology, Chinese Academy of Sciences, Nanjing 210008, P.R. China

(2) University of Chinese Academy of Sciences, Beijing 100049, P.R. China

* Corresponding author: fdzs4444@sina.com 
ces facteurs a contribué à une augmentation significative de la concentration en chlorophylle a pendant la saison des pluies; l'effet des nutriments sur le phytoplancton n'était pas évident. Les grandes variations dans le temps de rétention de l'eau au cours des trois saisons impliquent que le lac Poyang combine les caractéristiques d'une rivière et d'un lac. Les temps de rétention courts pendant les saisons sèche et mi-sèche n'entraînent aucune différence en chlorophylle a entre le lac et ses affluents, tandis que le temps de rétention long pendant la saison des pluies facilite la croissance du phytoplancton dans le lac.

\section{INTRODUCTION}

Phytoplankton can survive in a variety of aquatic environments, and the phytoplankton community is sensitive to environmental changes. In combination, these factors justify the importance of phytoplankton for tracking environmental changes in view of management issues involving aquatic ecosystems. Numerous studies have addressed the factors that disrupt the growth of phytoplankton, including abiotic (droughts and floods) and biotic factors (human pollution and grazing), and these studies have also estimated how ecosystems respond to stressors (Hein et al., 1999; Riedler et al., 2006; Vanni and Temte, 1990). Hydrological conditions, such as the water level, are the primary factors that affect phytoplankton, particularly in hydrologically variable environments. High levels of phytoplankton biomass have been observed during periods of low water levels, when more light and nutrients are available in temperate lakes (Nõges and Nõges, 1999; Nõges et al., 2003). Moreover, many studies have addressed patterns of phytoplankton variation during dry and wet seasons, particularly in floodplain ecosystems, rivers and estuaries, where the water level strongly affects the ecosystem (Burford et al., 2012; Huang et al., 2004; Zeng et al., 2006; Zinabu, 2002).

Lake Poyang is the largest freshwater lake in China. It has a storage capacity of approximately $2.95 \times 10^{10} \mathrm{~m}^{3}$ and is still connected to the Yangtze River in Hukou (Fu et al., 2003; Zhu and Zhang, 1997). The lake has five principal tributaries, all of which flow into Lake Poyang. The water level of Lake Poyang is determined by the discharge rates of the tributaries and by the balance between the Yangtze River and the lake (Shankman et al., 2006; Zhu and Zhang, 1997). Because of its ample natural resources, Lake Poyang plays an important role in local economic development and is subject to multiple stressors as a result of the human activities and abiotic factors that influence the lake ecosystem.

The limnological characteristics of Lake Poyang are strongly seasonal. This seasonality is related to differences in the water level during the dry, mid-dry and wet seasons. Although previous research has addressed the effect of the water level on energy flows in Lake Poyang (Wang et al., 2011), the patterns of variation in phytoplankton and the associated environmental factors during the dry, mid-dry and wet seasons remain unclear. Indeed, such studies will contribute to our knowledge of phytoplankton in river-connected and subtropical lakes. In addition, Lake Poyang is closely linked to its tributaries. These tributaries provide water to the lake and partly control the lake's water level. In lakes that are linked to rivers, phytoplankton can generally attain a biomass higher than that of the phytoplankton in the rivers (García de Emiliani, 1997). However, in this complex lake-river ecosystem, the patterns of phytoplankton variation involving Lake Poyang and its tributaries are not yet well known. A relatively long-term dataset that includes phytoplankton chlorophyll $a$ and physical-chemical and hydrological data from Lake Poyang and its tributaries may provide a basis for ecologically significant comparisons between the two types of systems.

Accordingly, the objectives of this study are as follows: to (1) determine the patterns of variation in phytoplankton chlorophyll $a$ and the associated environmental factors in Lake Poyang, and (2) comparatively analyse phytoplankton chlorophyll $a$ in the lake and its tributaries during the dry, mid-dry and wet seasons and identify the key factors responsible for producing the possible differences. 


\section{MATERIALS AND METHODS}

\section{$>$ STUDY AREA}

Lake Poyang $\left(28^{\circ} 22^{\prime}-29^{\circ} 45^{\prime} \mathrm{N}, 115^{\circ} 47^{\prime}-116^{\circ} 45^{\prime} \mathrm{E}\right)$ is located in Jiangxi Province in China in the downstream portion of the Yangtze River (Figure 1). The area of the Lake Poyang basin is $1.62 \times 10^{5} \mathrm{~km}^{2}$. The lake's five principal tributaries are the Gang River, Fu River, Xin River, Xiu River and Rao River, all flowing into the lake. The lake is approximately $4000 \mathrm{~km}^{2}$ in area during the wet season and decreases tenfold in area during the dry season (Shankman et al., 2006; Zhu and Zhang, 1997). The water level varies markedly between the dry and wet seasons, depending on the balance between the Yangtze River and Lake Poyang. The local rainfall also has an impact on the water level (Shankman et al., 2006; Wang, 2004; Zhu and Zhang, 1997). The rainy season normally begins in April in Jiangxi province. The discharge from the tributaries increases from April to June, raising the water level of the lake. The discharge from the tributaries then decreases from July to August as the water level in the Yangtze River increases; this increase impedes the drawdown of Lake Poyang, and water may even flow from the river into the lake. As a result, the highest water level occurs during this period (Zhu and Zhang, 1997). The water level of the lake begins to decrease in September following the drawdown of the Yangtze River, and the lowest water level in Lake Poyang usually occurs in January. The variation in the mean water level during the year is shown in Figure 2. This information is based on observations made at Duchang Hydrology Station (in the centre of the lake) from 1955 to 2011 . The mean water level was lowest in January $(10.51 \mathrm{~m})$ and highest in July (17.68 m), decreasing to $15.94 \mathrm{~m}$ in October. The annual average water level was $13.91 \mathrm{~m}$.

\section{> SAMPLE COLLECTION AND LAB ANALYSIS}

Sampling was conducted during the wet season (July 2009-2012), the dry season (January 2009, 2010, 2011 and 2013), and the mid-dry season (October 2009-2012) at 24 sites covering the lake and its main tributaries. Because of the intrinsic variation in the water level, it is possible to sample the lake adequately with extensive coverage in the wet season. To obtain more data on the entire lake, we added another sampling period in August $2011 \mathrm{cov}-$ ering 72 sites. This group of sites included the original sites. Furthermore, we added 61 sites to the original 24 sites in July 2012.

Selected environmental parameters, including salinity, $\mathrm{pH}$, water temperature $(T)$, dissolved oxygen (DO), turbidity and electrical conductivity, were obtained using a Hydrolab DataSonde 5 sensor in situ. The water transparency was determined using a Secchi disk. The vertically integrated water samples were collected with acid-cleaned 10-L plastic buckets and kept cool and shaded prior to transport to the laboratory. Suspended solids (SS), chemical oxygen demand $\left(\mathrm{COD}_{\mathrm{Mn}}\right)$ and nutrient concentrations, namely, total nitrogen (TN), total phosphorus (TP), dissolved total nitrogen (DTN), dissolved total phosphorus (DTP), ammonium $\left(\mathrm{NH}_{4}\right)$, nitrite $\left(\mathrm{NO}_{2}\right)$, nitrate $\left(\mathrm{NO}_{3}\right)$ and orthophosphate $\left(\mathrm{PO}_{4}\right)$, were analysed according to APHA (1998). The chlorophyll a concentration (chl a) was measured according to Lorenzen (1967) with spectrophotometric measurements after extraction in hot $90 \%$ ethanol and was used as the measure of phytoplankton biomass in this study.

The water retention time $(T)$ is typically expressed mathematically as $T=W / Q$, where $W=$ the lake volume $\left(\mathrm{m}^{3}\right)$ and $Q=$ the hydraulic outflow rate $\left(\mathrm{m}^{3} \cdot \mathrm{s}^{-1}\right)$. Given the highly variable hydrological conditions in Lake Poyang, we calculated $T$ values for different seasons. Our retention time calculations were based on long-term data, and $\mathrm{W}$ was calculated based on the monthly averaged water level at the Duchang Hydrology Station from 1955 to 2011 and on the curve of water level volumes in Lake Poyang. We collected the mean monthly value of $Q$ at Hukou, the site where water from Lake Poyang enters the Yangtze River, during the same period. The $T$ value in the wet season was defined as the mean $T$ value in July and August; the $T$ values in the dry and mid-dry seasons were defined as the $T$ values in January and October, respectively. 


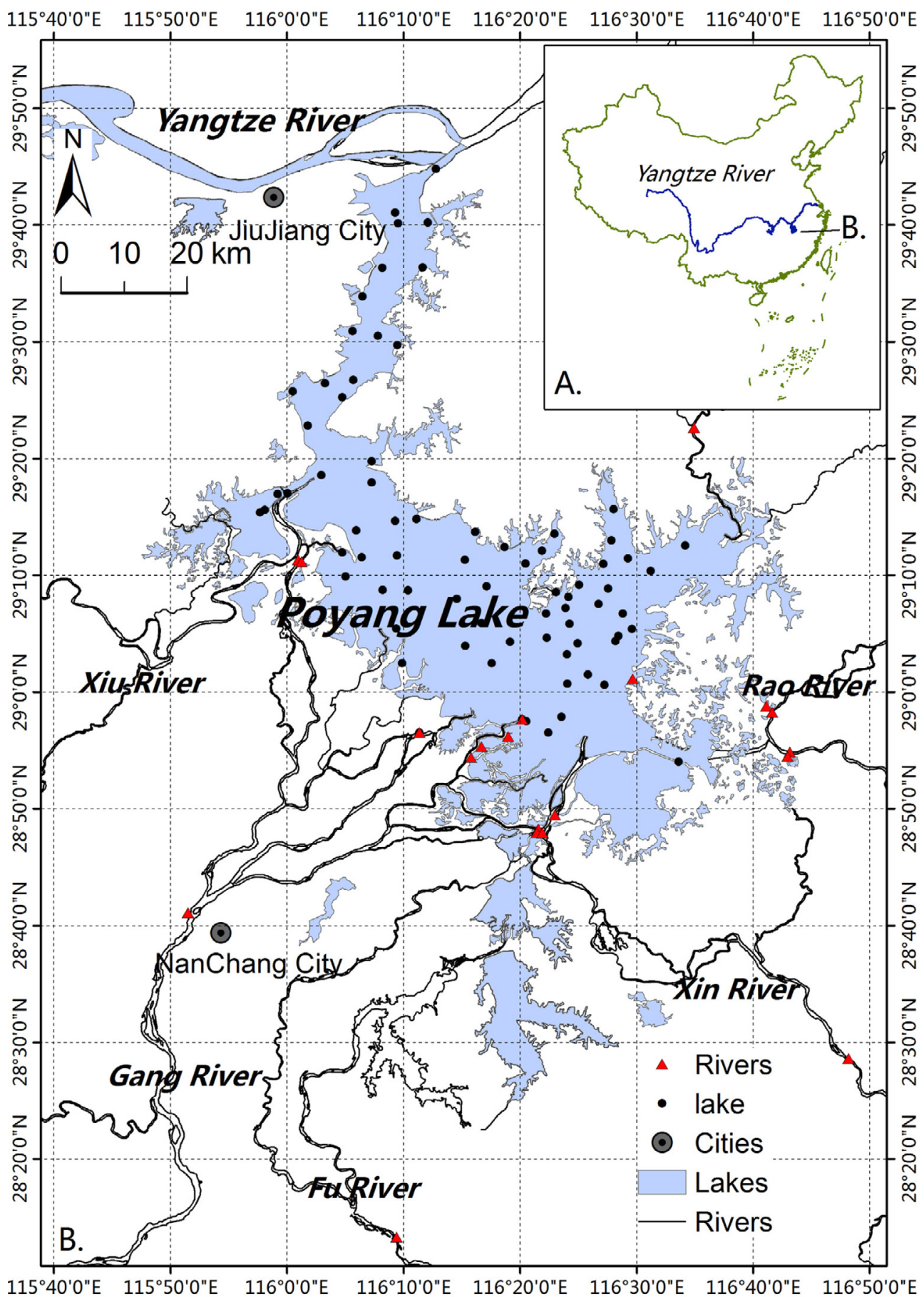

Figure 1

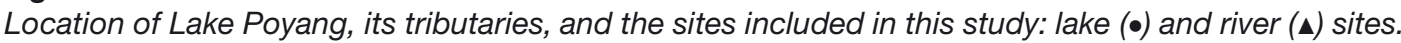

\section{> DATA ANALYSIS}

To detect relationships between phytoplankton chlorophyll a and environmental factors, the $\mathrm{chl}$ a data were averaged by season in both the lake and its tributaries. These averages were then compared with the corresponding average water transparency and SS concentration, which were representative of the underwater light conditions and nutrient concentrations, respectively. A notched box-whisker plot was used to illustrate the variation in chlorophyll a, water transparency, SS and nutrients (TN, TP, DTN, DTP, $\mathrm{NO}_{2}, \mathrm{NO}_{3}, \mathrm{NH}_{4}$ and $\mathrm{PO}_{4}$ ) during 


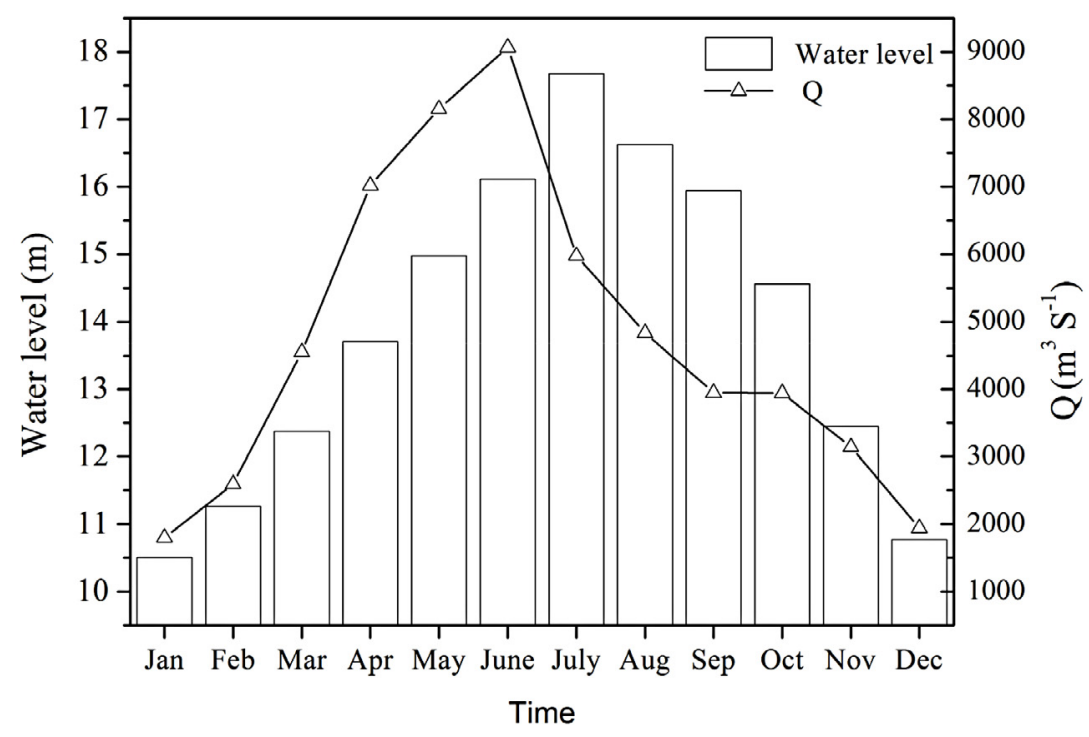

\section{Figure 2}

Average (1955-2011) monthly variation in water level (based on Duchang Hydrology Station data) in Lake Poyang and the hydraulic outflow rate, Q, from Lake Poyang to the Yangtze River.

the dry, mid-dry and wet seasons in the lake and the tributaries. Each vertical box shows the middle $50 \%$ of the data. The notch shown with the box and the small square represent the median and the mean, respectively. The whiskers show 1.5 times the interquartile range. Outliers are marked on the plot.

All statistical analyses were performed using PAST software (Paleontological Statistics v2.15) (Hammer et al., 2001), with the exception of Spearman's correlation analysis, which was performed using the statistical package SPSS for Windows (version 17.0). We employed nonparametric statistics because the lack of parameter normality precluded parametric statistical testing. Significance analyses for environmental factors and chlorophyll a were performed with Kruskal-Wallis nonparametric tests.

\section{RESULTS}

\section{> VARIATION IN CHL A AND ENVIRONMENTAL PARAMETERS DURING THE DRY AND MID-DRY SEASONS}

The results of the overall environmental parameters of the lake and its tributaries are presented in Table I. During the dry season, the concentration of chl a varied over a narrow range in the lake $\left(0.60-15.92 \mu \mathrm{g} \cdot \mathrm{L}^{-1}\right)$. This range was almost the same as that observed in the tributaries $\left(0.20-11.72 \mu \mathrm{g} \cdot \mathrm{L}^{-1}\right)$ and was similar to the variation during the mid-dry season. The chl a concentration did not differ significantly between the lake and the tributaries during the dry $(p=0.4674)$ and mid-dry $(p=0.6116)$ seasons (Figure 3 ).

The average water transparency and SS concentration differed significantly between the lake and its tributaries during the dry and mid-dry seasons. This result showed that the underwater light conditions were higher in the tributaries than in the lake. In the lake area, the average water transparency was almost the same during the dry and mid-dry seasons, 0.26 and $0.24 \mathrm{~m}$, respectively (Figure 4), and the SS concentration did not vary significantly.

All the mean nutrient concentrations in the lake decreased as the water level increased, with the exception of $\mathrm{NO}_{3}$ and $\mathrm{NO}_{2}$ (Figure 5). Regardless of the season, the mean nutrient concentrations were all greater in the tributaries than in the lake during the same period, with the exception of $\mathrm{TN}, \mathrm{NO}_{2}$ and $\mathrm{NO}_{3}$ during the dry season. 


\section{Table I}

Environmental variables summarised as mean values and ranges for the lake and its tributaries, during 2009-2013.

\begin{tabular}{|l|c|c|c|}
\hline \multirow{2}{*}{ Variable } & \multirow{2}{*}{ Unit } & \multicolumn{2}{|c|}{ Region } \\
\cline { 3 - 4 } & & Lake Poyang & The tributaries \\
\hline Transparency & $\mathrm{m}$ & $0.49(0.04-2.10)$ & $0.46(0.08-1.10)$ \\
\hline SS & $\mathrm{mg} \cdot \mathrm{L}^{-1}$ & $44.52(0.80-517.00)$ & $31.65(2.67-199.20)$ \\
\hline Turbidity & $\mathrm{NTU}$ & $61.43(3.10-970.00)$ & $42.53(1.40-340.20)$ \\
\hline Temperature & ${ }^{\circ} \mathrm{C}$ & $24.86(3.37-33.90)$ & $21.65(4.52-33.28)$ \\
\hline pH & & $7.99(6.85-9.30)$ & $7.81(6.56-9.14)$ \\
\hline Conductivity & $\mu \mathrm{S} \cdot \mathrm{cm}^{-1}$ & $129.12(56.10-780.00)$ & $150.91(51.80-497.50)$ \\
\hline DO & $\mathrm{mg} \cdot \mathrm{L}^{-1}$ & $7.60(2.01-19.92)$ & $8.22(3.40-18.79)$ \\
\hline Salinity & & $0.05(0.01-0.23)$ & $0.06(0.00-0.20)$ \\
\hline TN & $\mathrm{mg} \cdot \mathrm{L}^{-1}$ & $1.49(0.37-6.80)$ & $1.82(0.36-7.06)$ \\
\hline TP & $\mathrm{mg} \cdot \mathrm{L}^{-1}$ & $0.09(0.02-0.90)$ & $0.15(0.01-1.42)$ \\
\hline DTN & $\mathrm{mg} \cdot \mathrm{L}^{-1}$ & $1.30(0.19-2.61)$ & $1.63(0.24-6.45)$ \\
\hline DTP & $\mathrm{mg} \cdot \mathrm{L}^{-1}$ & $0.06(0.00-0.50)$ & $0.11(0.00-1.30)$ \\
\hline NO $_{2}$ & $\mathrm{mg} \cdot \mathrm{L}^{-1}$ & $0.03(0.00-0.33)$ & $0.06(0.00-0.74)$ \\
\hline NO $_{3}$ & $\mathrm{mg} \cdot \mathrm{L}^{-1}$ & $0.69(0.01-1.91)$ & $0.81(0.11-3.97)$ \\
\hline NH $_{4}$ & $\mathrm{mg} \cdot \mathrm{L}^{-1}$ & $0.21(0.01-1.56)$ & $0.55(0.02-5.78)$ \\
\hline PO $_{4}$ & $\mathrm{mg} \cdot \mathrm{L}^{-1}$ & $0.01(0.00-0.18)$ & $0.04(0.00-0.38)$ \\
\hline COD $_{\text {Mn }}$ & $\mathrm{mg} \cdot \mathrm{L}^{-1}$ & $3.02(1.28-13.01)$ & $2.81(1.21-6.54)$ \\
\hline Chlorophyll $\mathbf{a}$ & $\mu \mathrm{g} \cdot \mathrm{L}^{-1}$ & $7.86(0.60-34.37)$ & $4.76(0.20-20.31)$ \\
\hline
\end{tabular}

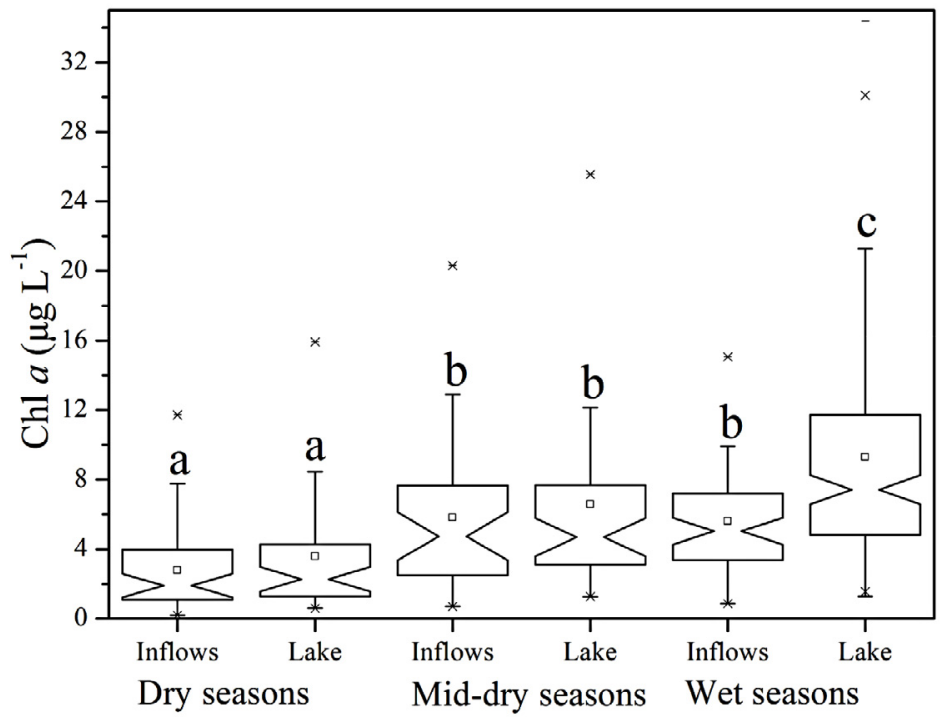

\section{Figure 3}

Variation in chl a concentrations between Lake Poyang and its tributaries during the dry, mid-dry and wet seasons. Means shown with different letters $(a, b, c)$ are significantly different $(p<0.05)$.

The water discharge from the lake to the Yangtze River was also recorded during the dry and mid-dry seasons, with values of $1799 \mathrm{~m}^{3} \cdot \mathrm{s}^{-1}$ and $3942 \mathrm{~m}^{3} \cdot \mathrm{s}^{-1}$, respectively (Figure 2). The water retention time changed markedly with the differences in the water levels, with values of 2.7 and $12.5 \mathrm{~d}$ during the dry and mid-dry seasons, respectively.

\section{> VARIATION IN CHL A AND ENVIRONMENTAL PARAMETERS DURING THE WET SEASON}

The maximum chl a concentration in the lake, $34.37 \mu \mathrm{g} \cdot \mathrm{L}^{-1}$, occurred during the wet season. The mean chl a concentration $\left(9.22 \mu \mathrm{g} \cdot \mathrm{L}^{-1}\right)$ was significantly greater than that in the other two 

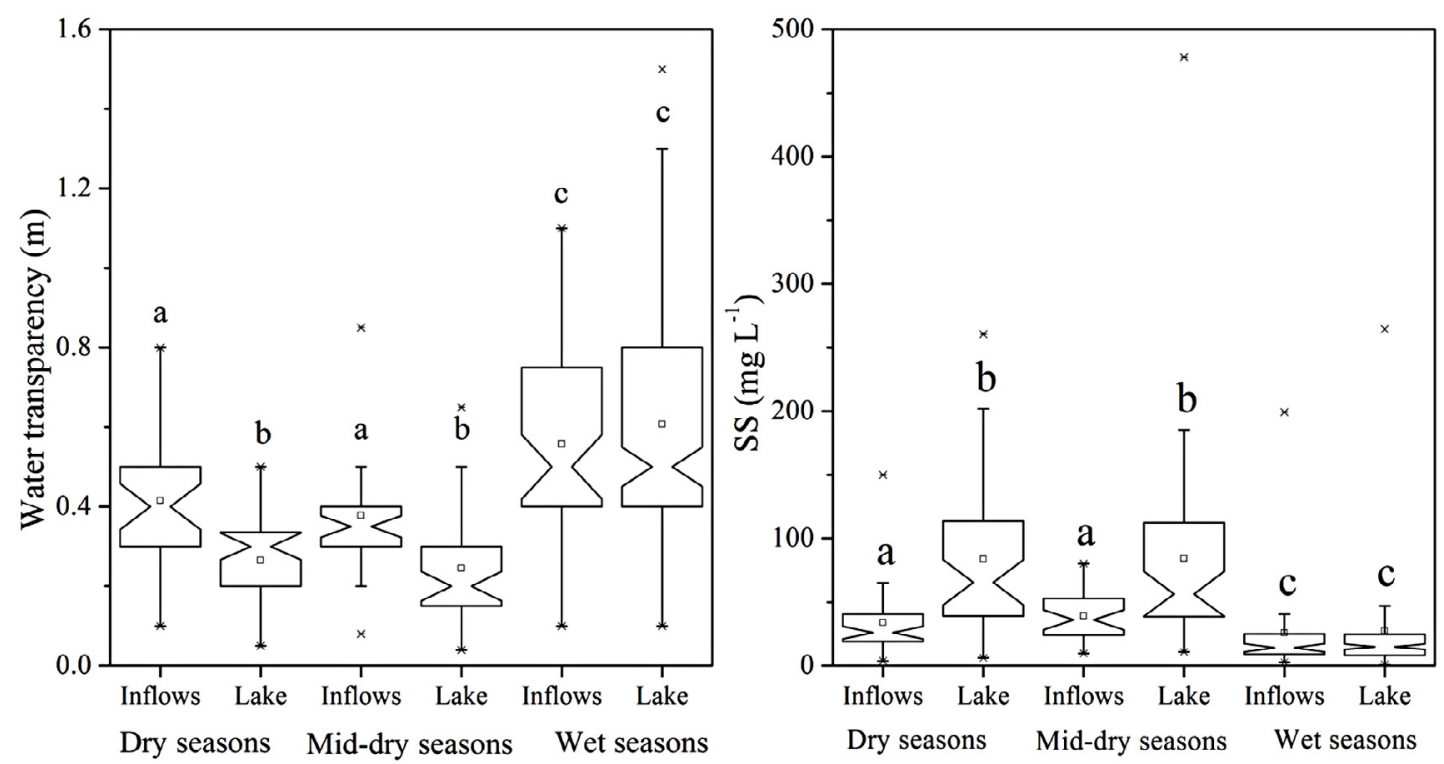

\section{Figure 4}

Variation in water transparency and SS between Lake Poyang and its tributaries during the dry, mid-dry and wet seasons. Means shown with different letters $(a, b, c)$ are significantly different $(p<0.05)$.

seasons (Figure 3). During the wet season, the fluctuations in chl a were much wider in the lake $\left(1.29-34.37 \mu \mathrm{g} \cdot \mathrm{L}^{-1}\right)$ than in the tributaries $\left(0.87-15.07 \mu \mathrm{g} \cdot \mathrm{L}^{-1}\right)$. The chl a concentration was significantly $(p<0.0001)$ greater in the lake than in the tributaries during the wet season. The water transparency in the lake during the wet season was significantly greater than that during the other two seasons $(p<0.001)$, with a mean value of $0.61 \mathrm{~m}$. The SS concentration decreased significantly during the wet season $(p<0.01)$. The trends of variation in the water transparency and SS in the tributaries were consistent with those in the lake (Figure 4). No significant differences in water transparency or SS concentrations were found between the tributaries and the lake during the wet season.

In the lake region, the nutrient concentrations (except that of $\mathrm{NO}_{2}$ ) were the lowest during the wet season, a time when the water level was the highest (Figure 5). The same phenomenon was also observed in the tributaries. The nutrient concentrations were all greater in the tributaries than in the lake during the wet season.

The water discharge from the lake to the Yangtze River was $5406 \mathrm{~m}^{3} \cdot \mathrm{s}^{-1}$ during the wet season. The water retention time was $25.5 \mathrm{~d}$ in Lake Poyang during the wet season, more than 2- and 9-fold greater than that during the mid-dry and dry seasons, respectively.

\section{> CORRELATION OF CHL A WITH ENVIRONMENTAL FACTORS}

A correlation analysis indicated that the chl a concentration was significantly positively correlated with water transparency and significantly negatively correlated with $\mathrm{SS}$ and nutrients (TN, TP, DTN, DTP, $\mathrm{NO}_{2}, \mathrm{NO}_{3}, \mathrm{NH}_{4}$ and $\mathrm{PO}_{4}$ ) in the lake regardless of the season (Table II). During the wet season, significant correlations were found between the chl a concentration and water transparency, $\mathrm{SS}$ and several nutrient concentrations $\left(\mathrm{TN}, \mathrm{NO}_{2}, \mathrm{NO}_{3}\right.$ and $\left.\mathrm{PO}_{4}\right)$. During the other seasons, the chl a concentration was not significantly correlated with the nutrient concentrations cited above except for TN and DTP in the dry season. In the tributaries, no significant correlation was found between the chl a concentration and water transparency and SS during the dry, mid-dry and wet seasons; an exception occurred during the wet season, when SS was negatively correlated with chl a. Few nutrient concentrations were found to be correlated with chl $a$ in the tributaries in all three seasons. 

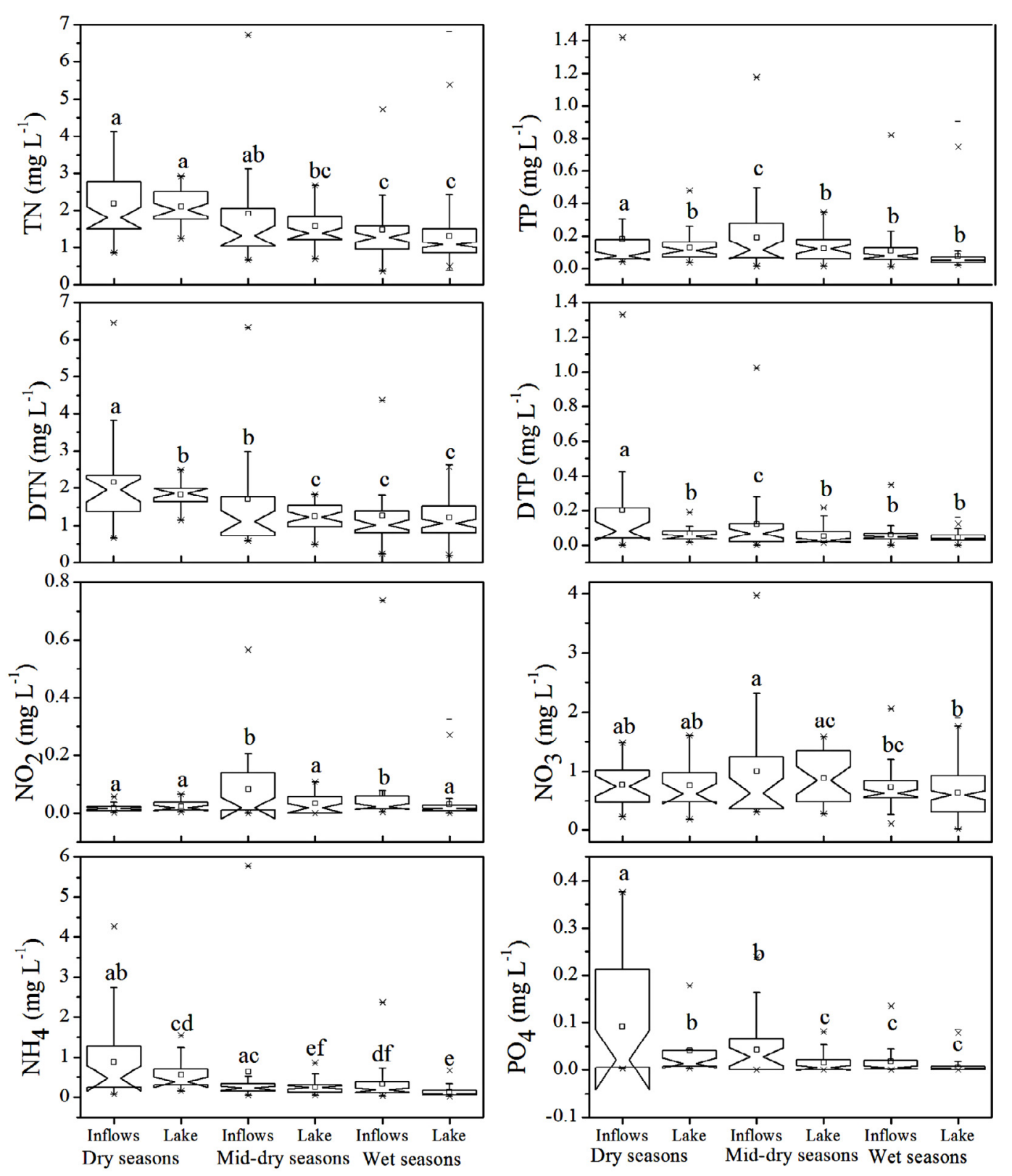

Figure 5

Variation in nutrient concentrations (TN, TP, DTN, DTP, $\mathrm{NO}_{2}, \mathrm{NO}_{3}, \mathrm{NH}_{4}$ and $\mathrm{PO}_{4}$ ) in Lake Poyang and its tributaries during the dry, mid-dry and wet seasons. Means shown with different letters $(a, b, c, d, e, f)$ are significantly different $(p<0.05)$.

\section{DISCUSSION}

Because of the lake's particular limnological characteristics, namely, its connection to the Yangtze River and its linkage to the tributaries, its water level varies widely during the dry, mid-dry and wet seasons. The water level variation produces changes in environmental factors such as light availability, nutrient concentrations and water retention time. In turn, these factors influenced phytoplankton growth in Lake Poyang and determined the differences between the lake and its tributaries.

Light: Light plays an important role in regulating phytoplankton growth because it provides the energy required for photosynthesis (Harris, 1978; Reynolds, 1984). In temperate lakes, relative to tropical lakes, light is more important than nutrients for restricting phytoplankton 


\section{Table II}

Spearman correlations for the relationships between chl a concentrations and transparency, SS and nutrient concentrations $\left(m g \cdot L^{-1}\right)$.

\begin{tabular}{|l|c|c|c|c|c|c|c|c|}
\cline { 2 - 9 } \multicolumn{1}{c|}{} & \multicolumn{4}{|c|}{ Lake Poyang } & \multicolumn{4}{c|}{ The tributaries } \\
\cline { 2 - 9 } \multicolumn{1}{c|}{} & Combined & Dry & Mid-dry & Wet & Combined & Dry & Mid-dry & Wet \\
\hline transparency & $0.432^{* *}$ & -0.193 & 0.204 & $0.301^{* *}$ & $0.223^{*}$ & 0.128 & 0.296 & 0.221 \\
\hline SS & $-0.424^{* *}$ & 0.163 & -0.174 & $-0.260^{* *}$ & $-0.272^{* *}$ & 0.108 & -0.329 & $-0.427^{\star *}$ \\
\hline TN & $-0.334^{* *}$ & $0.423^{* *}$ & -0.124 & $-0.184^{*}$ & $-0.207^{*}$ & -0.205 & 0.1 & -0.065 \\
\hline TP & $-0.219^{* *}$ & 0.198 & -0.032 & -0.066 & -0.1 & -0.164 & 0.212 & -0.219 \\
\hline DTN & $-0.202^{* *}$ & -0.256 & -0.243 & -0.044 & -0.17 & $-0.409^{*}$ & 0.088 & -0.042 \\
\hline DTP & $-0.159^{*}$ & $-0.470^{*}$ & -0.131 & -0.024 & -0.178 & $-0.677^{* *}$ & 0.278 & -0.22 \\
\hline $\mathbf{N O}_{2}$ & $-0.209^{* *}$ & 0.047 & -0.038 & $-0.281^{* *}$ & $0.206^{*}$ & -0.025 & $0.410^{*}$ & -0.074 \\
\hline $\mathbf{N O}_{3}$ & $-0.317^{* *}$ & -0.094 & -0.304 & $-0.344^{* *}$ & -0.136 & 0.195 & -0.045 & -0.077 \\
\hline $\mathbf{N H}_{4}$ & $-0.337^{* *}$ & -0.141 & 0.297 & -0.145 & $-0.278^{* *}$ & -0.046 & 0.251 & -0.195 \\
\hline $\mathbf{P O}_{4}$ & $-0.348^{* *}$ & -0.285 & -0.058 & $-0.195^{*}$ & -0.177 & -0.316 & 0.339 & -0.167 \\
\hline
\end{tabular}

${ }^{*} p<0.05 ;{ }^{* *} p<0.01$.

growth (Lewis, 1987). Furthermore, because the turbidity resulting from suspended particles affects light transmission and changes the light spectrum (Dokulil, 1984), the phytoplankton community is frequently limited by light in turbid ecosystems (Dokulil and Padisak, 1994; Lind et al., 1992). Lake Poyang is a turbid lake, and light availability is known to be the principal limiting factor in regulating phytoplankton growth in the lake (Wu et al., 2013). A correlation analysis showed that the chl a concentration was significantly correlated with the underwater light indicators (water transparency and SS). This result is consistent with the findings of Wu et al. (2013).

The underwater light level was significantly higher during the wet season than during the dry and mid-dry seasons. Water mixing and sediment resuspension appear to be the principal processes affecting water transparency and SS in Lake Poyang. Zhu and Zhang (1997) noted that the water flow rate was high during the dry season. Because the highest water levels of the Yangtze River and Lake Poyang both occurred during the wet season, the overall water flow rate of Lake Poyang decreased, reducing the degree of water mixing and causing the suspended sediment to settle. In turn, these changes increased the underwater light conditions and contributed to the peak value of chl $a$ in the wet season in Lake Poyang.

Nutrients: As basic chemical elements, nitrogen and phosphorus have been shown to affect phytoplankton growth (Reynolds, 1984; Xu et al., 2010). Increasing nutrient inputs drive the rapid growth of phytoplankton and cause serious eutrophication problems, particularly the appearance of harmful algal blooms, in various ecosystems (Chen et al., 2003; Moss et al., 1996). In Lake Poyang, almost all the nutrient concentrations decreased as the water level increased, reaching their lowest values during the wet season, in contrast to the trend shown by the phytoplankton. Two factors may explain this difference. First, the lake volume increased as the water level increased, and it is probable that the concentrations of nutrients decreased due to dilution. Second, Lake Poyang primarily receives water from its tributaries, but the concentrations of nutrients (TN, DTN, DTP, $\mathrm{NH}_{4}$ and $\mathrm{PO}_{4}$ ) in the tributaries decreased from the dry season to the wet season, and $\mathrm{TP}$ and $\mathrm{NO}_{3}$ also reached their lowest values during the wet season.

Few significant correlations between chl $a$ and the nutrient concentrations were found in the lake, especially in the dry and mid-dry seasons. Regardless of the season, these correlations were all negative in the lake. These findings appear to indicate that nutrients were relatively less important as determinants of phytoplankton production in Lake Poyang. However, according to Wu et al. (2013), the annual trends in phytoplankton chlorophyll a were associated with nutrient concentrations, which increased yearly and initiated the growth of phytoplankton. In general, the variations in nutrient concentrations during the dry, mid-dry and wet seasons depended on the water level. This dependence masked the effects of nutrients on phytoplankton production. 
Water retention time: The water retention time is a crucial factor affecting algal growth, particularly in river systems, which frequently have water retention times of only a few days (Moss et al., 1989; Reynolds, 1994; Straskraba, 1999; Vollenweider, 1976). In general, a longer water retention time will benefit phytoplankton (García de Emiliani, 1997; Søballe and Kimmel, 1987). The water retention time of Lake Poyang is relatively low, approximately 10 days (Zhu and Zhang, 1997), a value that is considerably less than those of two other large freshwater lakes in China, Lake Taihu and Lake Chaohu, with retention times of 264 and $127 \mathrm{~d}$, respectively (Jin et al., 1990). Furthermore, the water retention time varies among seasons in Lake Poyang, with low values in the dry (2.7 d) and mid-dry (12.5 d) seasons but a comparatively high value in the wet season $(25.5 \mathrm{~d})$. We found a mean water retention time of $13.6 \mathrm{~d}$, consistent with the value of $10 \mathrm{~d}$ found by Zhu and Zhang (1997). As stated above, water can flow freely from Lake Poyang into the Yangtze River during the dry and mid-dry seasons, resulting in a short water retention time. However, the water level is in balance between the Yangtze River and the lake during the wet season, and water may even flow from the Yangtze River into the lake. As a result, the retention time is relatively greater and can be expected to facilitate the growth of phytoplankton (Sullivan et al., 2001).

Water retention time also plays an important role in determining the difference in phytoplankton chl a between Lake Poyang and its tributaries. Our study found that the phytoplankton $\mathrm{chl} a$ in the lake was significantly greater than that in its tributaries during the wet season. In contrast, no significant difference in phytoplankton chl a was observed between the two ecosystems during the dry and mid-dry seasons. Light availability and nutrients cannot explain this inconsistency. The underwater light conditions were significantly higher in the tributaries than in the lake during the dry and mid-dry seasons and almost the same during the wet season; almost all the nutrient concentrations were higher in the tributaries in all seasons. Fewer significant correlations were found between the chl a concentrations and physical and chemical factors in the lake during the dry and mid-dry seasons than during the wet season; there were also a few significant correlations in the tributaries during all three seasons. These results may indicate that phytoplankton growth was not strongly influenced by light and nutrients in the lake during the dry and mid-dry seasons, and in the tributaries. Other studies have found that hydrology, such as water retention time, determines phytoplankton development in rapidly flushed ecosystems (Hein et al., 1999; Søballe and Kimmel, 1987; Zeng et al., 2006). Therefore, we hypothesised that hydrological conditions, specifically the retention time, represented the principal factor controlling phytoplankton growth in both the lake during the dry and mid-dry seasons and the tributaries during all three seasons. Water retention time is a useful indicator of the similarities and differences among aquatic ecosystems (Søballe and Kimmel, 1987). As stated above, the water retention time of Lake Poyang changed markedly over the seasons. However, it is difficult to calculate a retention time for the tributaries; nevertheless, that time is obviously brief, perhaps a few days, in view of the results of previous studies in other regions (Søballe and Kimmel, 1987) and our judgement and experience in the basin of Lake Poyang. Because of short retention times during the dry and mid-dry seasons, insufficient time is available for the phytoplankton populations to increase, and no differences develop between the lake and its tributaries. In contrast, the longer retention time of the lake during the wet season results in a significantly higher accumulation of phytoplankton in the lake. This finding is consistent with the results of previous studies in similar ecosystems (García de Emiliani, 1990; García de Emiliani, 1997).

\section{> COMPARISONS WITH OTHER AREAS}

Many studies have addressed variations in phytoplankton occurring between the dry and wet seasons. Water level variation changes the chemical characteristics of the water in the lake ecosystem (Pęczuła and Szczurowska, 2013). Zinabu (2002) noted that certain lakes show greater chl a concentrations due to higher nutrient concentrations during the wet season, whereas other turbid and less productive lakes are light-limited, most likely producing higher chl a concentrations during the dry season. Similar to Lake Poyang, Lake Montiel and Lake 
El Tigre are connected to a river (the Parana River) during the period of rising river levels. Izaguirre et al. (2001) found that poor light availability was associated with low water levels in Lake Montiel. This combination of factors limited algal growth. In Lake El Tigre, water transparency was also significantly and positively correlated with lake depth (García de Emiliani, 1997). In another large Yangtze-connected lake, Lake Dongting, few studies have been conducted on the effect of water level on phytoplankton growth, and comparisons of these two ecosystems are not available. In Lake Poyang, we found that high phytoplankton chlorophyll a was observed during the wet season due to greater light availability and relatively longer water retention time.

Differences in phytoplankton between rivers and lakes are also of interest to ecologists. Søballe and Kimmel (1987) compared a large number of rivers, lakes and river impoundments and suggested that algal abundance increased with residence time. In Lake El Tigre, phytoplankton biomass was higher in the lake than in the river (García de Emiliani 1997). The water retention time was shown to be the crucial factor determining the difference between lakes and rivers regardless of whether they were linked. In Lake Poyang, the substantial variations in the water level not only affect the underwater light conditions and nutrients but also change the water retention time seasonally. The various water retention times in Lake Poyang determine the combined limnological characteristics of the lake and the river and, most likely, cause the differences between the lake and its tributaries. In summary, light availability and water retention time are the main variables controlling the chl a concentration in Lake Poyang. The water level should become the indicator of phytoplankton growth, which is important for management of the lake. If the water level is continuously high, certain ecological problems, such as algal blooms, may occur.

\section{ACKNOWLEDGEMENTS}

We thank the Lake Poyang Laboratory for Wetland Ecosystem Research (PLWER) for providing the foundation for the experiment. We are grateful to $\mathrm{Dr} \mathrm{Hu} \mathrm{He}$ and $\mathrm{Dr}$ Lei Zhang for their constructive suggestions. This study was financially supported by the National Basic Research Program of China (grant 2012CB417005), National Natural Science Foundation of China (41301088) and Science and Technology Major Project of Jiangxi Province (Grant 20114ABG01100).

\section{REFERENCES}

American Public Health Association, 1998. Standard Methods for the Examination of Water and Waste Water, 20th edn., Washington, DC.

Burford M., Webster I., Revill A., Kenyon R., Whittle M. and Curwen G., 2012. Controls on phytoplankton productivity in a wet-dry tropical estuary. Estuar. Coast. Shelf Sci., 113, 141-151.

Chen Y.W., Qin B.Q., Teubner K. and Dokulil M.T., 2003. Long-term dynamics of phytoplankton assemblages: Microcystis-domination in Lake Taihu, a large shallow lake in China. J. Plankton Res., 25, 445-453.

Dokulil M.T., 1984. Assessment of components controlling phytoplankton photosynthesis and bacterioplankton production in a shallow, alkaline, turbid lake (Neusiedlersee, Austria). Int. Rev. Gesamten Hydrobiol., 69, 679-727.

Dokulil M.T. and Padisak J., 1994. Long-term compositional response of phytoplankton in a shallow, turbid environment, Neusiedlersee (Austria/Hungary). Hydrobiologia, 275, 125-137.

Fu C.Z., Wu J.H., Chen J.K., Qu Q.H. and Lei G.C., 2003. Freshwater fish biodiversity in the Yangtze River basin of China: patterns, threats and conservation. Biodivers. Conserv., 12, 1649-1685.

García de Emiliani M.O., 1990. Phytoplankton ecology of the middle Paraná River. Acta Limnol. Bras., 3, 391-417.

García de Emiliani M.O., 1997. Effects of water level fluctuations on phytoplankton in a river-floodplain lake system (Paraná River, Argentina). Hydrobiologia, 357, 1-15. 
Hammer Ø., Harper D. and Ryan P., 2001. PAST: palaeontological statistics software package for education and data analysis. Palaeontologia electronica, 4, 9.

Harris G.P., 1978. Photosynthesis, productivity and growth: the physiological ecology of phytoplankton. Arch. Hydrobiol. Beih. Ergebn. Limnol., 10, 1-163.

Hein T., Baranyi C., Heiler G., Holarek C., Riedler P. and Schiemer F., 1999. Hydrology as a major factor determining plankton development in two floodplain segments and the River Danube, Austria. Arch. Hydrobiol. Suppl., 115, 439-452.

Huang L.M., Jian W.J., Song X.Y., Huang X.P., Liu S., Qian P.Y., Yin K.D. and Wu M., 2004. Species diversity and distribution for phytoplankton of the Pearl River estuary during rainy and dry seasons. Mar. Pollut. Bull., 49, 588-596.

Izaguirre I., O'Farrell I. and Tell G., 2001. Variation in phytoplankton composition and limnological features in a water-water ecotone of the Lower Paraná Basin (Argentina). Freshwater Biol., 46, 63-74.

Jin X.C., Liu H.L., Tu Y.Q., Zhang Z.X. and Zhu X., 1990. Eutrophication of lakes in China, Chinese Research Academy of Environmental Sciences, Beijing.

Lewis W.M., 1987. Tropical limnology. Annu. Rev. Ecol. Syst., 18, 159-184.

Lind O.T., Doyle R., Vodopich D.S., Trotter B.G., Limón J.G. and Davalos-Lind L., 1992. Clay turbidity: regulation of phytoplankton production in a large, nutrient-rich tropical lake. Limnol. Oceanogr., 37, 549-565.

Lorenzen C.J., 1967. Determination of chlorophyll and pheo-pigments: spectrophotometric equations. Limnol. Oceanogr. 12, 343-346.

Moss B., Booker I., Balls H. and Manson K., 1989. Phytoplankton distribution in a temperate floodplain lake and river system. I. Hydrology, nutrient sources and phytoplankton biomass. J. Plankton Res., 11, 813-838.

Moss B., Madgwick J., Phillips G., 1996. A guide to the restoration of nutrient-enriched shallow lakes. Broads Authority, Norwich, UK, $180 \mathrm{p}$.

Nõges T. and Nõges P., 1999. The effect of extreme water level decrease on hydrochemistry and phytoplankton in a shallow eutrophic lake. Hydrobiologia, 408, 277-283.

Nõges T., Nõges P. and Laugaste R., 2003. Water level as the mediator between climate change and phytoplankton composition in a large shallow temperate lake. Hydrobiologia, 506, 257-263.

Pęczuła W. and Szczurowska A., 2013. Long-term changes in phytoplankton in a humic lake in response to the water level rising: the effects of beaver engineering on a freshwater ecosystem. Knowledge Managt. Aquatic Ecosyst., 410, 06.

Reynolds C.S., 1984. The Ecology of Freshwater Phytoplankton, Cambridge University Press, London.

Reynolds C.S., 1994. The long, the short and the stalled: on the attributes of phytoplankton selected by physical mixing in lakes and rivers. Hydrobiologia, 289, 9-21.

Riedler P., Barany C., Hein T., Keckeis S. and Schagerl M., 2006. Abiotic and biotic control of phytoplankton development in dynamic side-arms of the River Danube. Austria. Arch. Hydrobiol. Suppl., 16, 577-594.

Rojo C., Cobelas M.A. and Arauzo M., 1994. An elementary, structural analysis of river phytoplankton. Hydrobiologia, 289, 43-55.

Søballe D.M., and Kimmel B.L., 1987. A large-scale comparison of factors influencing phytoplankton abundance in rivers, lakes, and impoundments. Ecology, 68, 1943-1954.

Shankman D., Keim B.D. and Song J., 2006. Flood frequency in China's Poyang Lake region: Trends and teleconnections. Int. J. Climatol., 26, 1255-1266.

Sullivan B., Prahl F., Small L. and Covert P., 2001. Seasonality of phytoplankton production in the Columbia River: A natural or anthropogenic pattern? Geochim. Cosmochim. Acta, 65, 1125-1139.

Straskraba M., 1999. Retention time as a key variable of reservoir limnology. In: Theoretical reservoir ecology and its applications (eds J.G. Tundisi \& M. Straskraba). Sao Carlos: International Institute of Ecology, Brazilian Academy and Backhuys Publishers, 385-410.

Vanni M.J. and Temte J., 1990. Seasonal patterns of grazing and nutrient limitation of phytoplankton in a eutrophic lake. Limnol. Oceanogr., 35, 697-709.

Vollenweider R.A., 1976. Advances in defining critical loading levels for phosphorus in lake eutrophication. Mem. Ist. Ital. Idrobiol., 33, 53-83

Wang X.H., 2004. Evaluation on Poyang Lake Wetland Ecosystem (in Chinese), Science Press, Beijing. 
Wang Y.Y., Yu X.B., Li W.H., Xu J., Chen Y.W. and Fan N., 2011. Potential influence of water level changes on energy flows in a lake food web. Chinese Sci. Bull., 56, 2794-2802.

Wu Z.S., Cai Y.J., Liu X., Xu C.P., Chen Y.W. and Zhang L., 2013. Temporal and spatial variability of phytoplankton in Lake Poyang: The largest freshwater lake in China. J. Great Lakes Res., 39, 476-483.

Xu H., Paerl H.W., Qin B.Q, Zhu G.W. and Gao G., 2010. Nitrogen and phosphorus inputs control phytoplankton growth in eutrophic Lake Taihu, China. Limnol. Oceanogr., 55, 420-432.

Zeng H., Song L.R., Yu Z.G. and Chen H.T., 2006. Distribution of phytoplankton in the Three-Gorge Reservoir during rainy and dry seasons. Sci. Total Environ., 367, 999-1009.

Zhu H.H. and Zhang B. 1997. The Poyang Lake, University of Science \& Technology of China Press, Hefei (in Chinese).

Zinabu G.M., 2002. The effects of wet and dry seasons on concentrations of solutes and phytoplankton biomass in seven Ethiopian rift-valley lakes. Limnologica, 32, 169-179. 